\title{
Association between physical function and onset of coronary heart disease in a cohort of community- dwelling older populations: The Septuagenarians, Octogenarians, Nonagenarians Investigation with Centenarians study
}

\section{Nonglak Klinpudtan}

Graduate School of Medicine, Osaka University

Mai Kabayama

Graduate School of Medicine, Osaka University

\section{Kayo Godai}

Graduate School of Medicine, Osaka University

\section{Yasuyuki Gondo}

Graduate School of Human Sciences, Osaka University

\section{Yukie Masui}

Tokyo Metropolitan Geriatric Hospital and Institute of Gerontology

\section{Yuya Akagi}

Graduate School of Medicine, Osaka University

Werayuth Srithumsuk

Graduate School of Medicine, Osaka University

\section{Eri Kiyoshige}

Graduate School of Medicine, Osaka University

\section{Ken Sugimoto}

Graduate School of Medicine, Osaka University

\section{Hiroshi Akasaka}

Graduate School of Medicine, Osaka University

\section{Yoichi Takami}

Graduate School of Medicine, Osaka University

\section{Yasushi Takeya}

Graduate School of Medicine, Osaka University

\section{Koichi Yamamoto}

Graduate School of Medicine, Osaka University

Kazunori lkebe

Graduate School of Dentistry, Osaka University 


\section{Saori Yasumoto}

Graduate School of Human sciences, Osaka University

\section{Madoka Ogawa}

Tokyo Metropolitan Geriatric Hospital and Institute of Gerontology

\section{Hiroki Inagaki}

Tokyo Metropolitan Geriatric Hospital and Institute of Gerontology

\section{Tatsuro Ishizaki}

Tokyo Metropolitan Geriatric Hospital and Institute of Gerontology

\section{Yasumichi Arai}

Keio University School of Medicine, Tokyo

\section{Hiromi Rakugi}

Graduate School of Medicine, Osaka University

Kei Kamide ( $\boldsymbol{\sigma}$ kamide@sahs.med.osaka-u.ac.jp )

Graduate School of Medicine, Osaka University

\section{Research note}

Keywords: Walking speed, Grip strength, Angina pectoris, Myocardial infarction, Older adults

Posted Date: August 28th, 2020

DOI: https://doi.org/10.21203/rs.3.rs-65466/v1

License: (c) (i) This work is licensed under a Creative Commons Attribution 4.0 International License. Read Full License 


\section{Abstract}

Objective: Physical function is a strong predictor of the adverse outcomes in older populations. We prospectively examined the association of walking speed and handgrip strength with CHD in the community-dwelling older populations. The study cohort in Japan included 1272 older people free from heart disease at the baseline. Physical function was identified based on walking speed and handgrip strength assessment at the survey site. Any new case of CHD was obtained based on a self-reported doctor's diagnosis. Cox-proportion hazard models were adjusted for covariate factors to examine the CHD risk.

Results: During the 7-year follow-up, 45 new cases of CHD were documented. Slow walking speed was strongly associated with CHD risk after adjusting for all confounding factors in the total participants and women (hazard ratio $(H R)=2.53,95 \%$ confidence interval $(C l), 1.20-5.33, p=0.015$, and $H R=4.78,95 \%$ $\mathrm{Cl}, 1.07-21.35, \mathrm{p}=0.040$, respectively), but not in men. Weak grip strength was associated with $\mathrm{CHD}$ after age-adjustment $(\mathrm{HR}=2.45,95 \% \mathrm{Cl}, 1.03-5.81, \mathrm{p}=0.043)$ only in men. However, after additional multivariate adjustment, the associations were weaker. The results lead to the conclusion that, after multivariate adjustment for coronary heart disease, walking speed is a strong surrogate predictor of the CHD risk among older people.

\section{Introduction}

Coronary heart disease (CHD) is the leading cause of premature death worldwide, the incidence increasing by age [1, 2]. We now know the traditional risk factor such as hypertension, diabetes, smoking, and so on are the major risk factors of $\mathrm{CHD}$ [3-6]. In recent decade, many studies have shown that improving the physical function can help cardiovascular mortality, and improve well-being in older populations [7-9]. Walking speed and grip strength were used as surrogate markers of the physical function and represented the main determinants of physical frailty and sarcopenia. These markers are simple risk stratification tools, reliable, and valid measures of the functional status. Walking speed and grip strength have been shown to be strong predictors of survival, cardiovascular disease (CVD) mortality, and hospitalizations [10-17]. Nonetheless, studies in the older populations are very limited, and most research used only one method for investigating the outcomes, whereas both methods were used in a few studies. Therefore, investigating whether associations persist after adjusting for both walking speed and grip strength will further help elucidate the potential clinical importance of coronary heart disease within older populations who live in the community.

The study aimed to determine the association of walking speed and grip strength with coronary heart disease in community-dwelling older populations, and we also sex-stratified subjects because the muscle strength is influenced by the sex.

\section{Main Text}




\section{Research methods}

Participants were recruited from the SONIC study which is a cohort study of community-dwelling old populations of Japan. The SONIC term comes from Septuagenarians, Octogenarians, Nonagenarians, and Investigation with Centenarians [18]. This study used data from the baseline of the 70, 80, and 90 year-old groups in 2010, 2011, and 2012, respectively, until the end of the follow-up in 2018. The subjects eligible for the study had been followed up at least 1 time and were free from heart disease at the baseline. Severe paralysis, stroke, and Parkinson patients were excluded from the study. All participants provided written informed consent to participate on-site prior to starting the survey.

\section{Physical Function}

Walking speed and handgrip strength were surrogates of the physical function in this study. Walking speed was assessed at the baseline by measuring the time taken in 2 trials to walk a 2.44-meter course. Slow walking speed was defined as an average walking speed $<1 \mathrm{~m} / \mathrm{s}$ [19] based on two trials of the 2.44-meter walk test. We instructed all participants to walk at a normal speed from a standing start. Grip strength was assessed twice by a hand dynamometer in kilogram units on the dominant side. The average value was used for analysis. Weak grip strength was identified according to the Asian working group for sarcopenia consensus (AWGS) as $<26 \mathrm{~kg}$ for men and $<18 \mathrm{~kg}$ for women [20].

\section{Main Outcome}

The outcome of the study was new cases of coronary heart disease (CHD) at the follow-up. Based on the questionnaire, we assessed the history of heart disease depending on whether the participants had been diagnosed by a doctor. The participants were asked about their specific type of heart disease. CHD was identified as a history of myocardial infarction or angina pectoris based on a medical diagnosis selfreport.

Covariate Factors and Other Measurements: We considered covariate factors in the association between physical function and CHD. Diabetes mellitus (DM) was classified as fasting blood glucose $\geq 126 \mathrm{mg} / \mathrm{dL}$ or random blood glucose testing $\geq 200 \mathrm{mg} / \mathrm{dL}$, Hemoglobin A1c (National Glycohemiglobin Standardization Program (NGSP)) $\geq 6.5 \%$, or taking medication for diabetes [21]. Hypertension (HT) was classified as systolic blood pressure $\geq 140 \mathrm{mmHg}$ or diastolic blood pressure $\geq 90 \mathrm{mmHg}$ or being on antihypertensive treatment [22]. Dyslipidemia (DLP) was classified as low-density lipoprotein cholesterol $(\mathrm{LDL}) \geq 140 \mathrm{mg} / \mathrm{dL}$, high-density lipoprotein cholesterol $(\mathrm{HDL})<40 \mathrm{mg} / \mathrm{dL}$, triglycerides $(\mathrm{TG}) \geq$ $150 \mathrm{mg} / \mathrm{dL}$, or taking medication for dyslipidemia according to the Japan Atherosclerosis Society (JAS) [23]. Those definitions were based on the standard for people of all ages in Japanese guidelines. The body mass index (BMI) was calculated as the weight in kilograms divided by the height in meters squared. The smoking experience was divided into two groups: never and ever (current or past smoker) smoking based on a questionnaire.

The carotid ultrasound was used for measure between the intimal-luminal and medial-adventitial interfaces of the carotid artery. The intima-media thickness (IMT) is a space between the two hyperechoic 
lines [24]. The procedure was performed by a physician. The average IMT value between left and right sides of the carotid was used for analysis $[25,26]$. Blood specimens and physical examinations were performed by a physician or registered nurses.

Statistical Analysis: Descriptive statistics were used to examine participant characteristics to determine the status of the physical function according to Japanese society guidelines. The association between the physical function and CHD over the follow-up was assessed using Cox proportional involved 4 models using those variables were revealed on which are traditional risk factors of $\mathrm{CHD}$. Both walking speed and grip strength were simultaneously entered across all models and then adjusted for multivariate factors: model 1 included demographic covariates (age and sex); model 2 was adjusted for vascular disease (HT, DM, DLP) and included model 1; model 3 was adjusted for lifestyle factors (BMI and smoking experience) and included model 1; model 4 (fully adjusted) was adjusted as in model 2 and included model 3. We then investigated whether sex differentiated these associations in models 1 to 4 . We used SPSS version 24 software for all analyses. The results are reported with $95 \%$ confidence intervals; a two-sided $\mathrm{p}$-value $<.05$ was considered significant.

\section{Results}

The analyses were based on 1272 participants who met the inclusion criteria from a total of 2245 participants. During 7-year follow-up, 45 (3.5\%) newly patients reported experienced CHD. The prevalence of slow walking was likely to be higher in the CHD group. The prevalence of coronary heart disease was more likely to be higher in men with the 70-year-old group (Table 1). The characteristics of the participants according to the status of walking speed and grip strength at the baseline are presented in Table 2 for all participants and Additional file 1 Table S1 for sex stratifications. The highest prevalence of slow walking speed and weak grip strength was in the 80-year-old group in all participants and both sexes. Individuals with slow walking speed were more likely to be HT, weak grip strength, lower serum albumin, and higher IMT on considering all participants and sex stratifications. Individuals with weak grip strength were more likely to be those who had slow walking speed, lower serum albumin, lower TCHO, lower BMI, and higher IMT on considering all participants and sex stratifications. The prevalence of physical function status stratified by age and sex are presented in Additional file 2 figure S1. Those with weak grip strength were more likely to be women in the 70 and 80-year-old groups. Whereas, those with a slow walking speed were more likely to be women in the 70-year-old group.

Table1. Individual characteristics at the baseline according to CHD over 7-year follow-up ( $N=1272)$ 


\begin{tabular}{|c|c|c|c|}
\hline \multirow[t]{2}{*}{ Characteristics } & & \multicolumn{2}{|c|}{ CHD onset over 7-year follow-up } \\
\hline & & Without CHD & With CHD \\
\hline \multirow[t]{2}{*}{ Sex } & Men & $553(45.1)$ & $25(55.6)$ \\
\hline & Women & $674(54.9)$ & $20(44.4)$ \\
\hline \multirow[t]{3}{*}{ Age group } & $70 \mathrm{y}$ & $560(45.6)$ & $19(42.2)$ \\
\hline & $80 \mathrm{y}$ & $586(47.8)$ & $23(51.1)$ \\
\hline & $90 \mathrm{y}$ & $81(6.6)$ & $3(6.7)$ \\
\hline \multicolumn{2}{|l|}{ DM yes, (\%) } & $193(15.7)$ & $8(17.8)$ \\
\hline \multicolumn{2}{|l|}{ HT yes, (\%) } & $883(72)$ & $36(80)$ \\
\hline \multicolumn{2}{|l|}{ DLP yes, $(\%)$} & $729(59.4)$ & $31(68.9)$ \\
\hline \multicolumn{2}{|l|}{ Ever-smoker } & $443(36.1)$ & $18(40.0)$ \\
\hline \multicolumn{2}{|l|}{$\mathrm{BMI}\left(\mathrm{kg} / \mathrm{m}^{2}\right), \mathrm{M}(\mathrm{SD})$} & $22.6(3.2)$ & $22.9(3.5)$ \\
\hline \multicolumn{2}{|l|}{ Slow walking, n (\%) } & $767(62.5)$ & $36(80)$ * \\
\hline \multicolumn{2}{|l|}{ Weak grip strength, $\mathrm{n}(\%)$} & $506(41.2)$ & $20(44.4)$ \\
\hline \multirow[t]{2}{*}{$70 \mathrm{y}}$. & Men & $244(43.6)$ & $14(73.7)$ ** \\
\hline & Women & $316(56.4)$ & $5(26.3)$ \\
\hline \multirow[t]{2}{*}{$80 \mathrm{y}}$. & Men & $274(46.8)$ & $11(47.8)$ \\
\hline & Women & $312(53.2)$ & $12(52.2)$ \\
\hline \multirow[t]{2}{*}{90 y. } & Men & $35(43.2)$ & $0(0)$ \\
\hline & Women & $46(56.8)$ & $3(100)$ \\
\hline \multirow[t]{4}{*}{ Years of follow-up } & 3 & $357(29.1)$ & $21(46.7)$ \\
\hline & 4 & $24(2)$ & $0(0)$ \\
\hline & 6 & 757 (61.7) & $24(53.3)$ \\
\hline & 7 & $89(7.3)$ & $0(0)$ \\
\hline
\end{tabular}

CHD indicates coronary heart disease; DM, Diabetes mellitus; HT, Hypertension; DLP, Dyslipidemia, BMI, Body mass index; SD, Standard deviation. * significant with p-value $<0.05$, $* \star p$-value $<0.01$ on chi-square analysis, +See text on physical function of methods for details on how the status was defined.

Table 2. The characteristics of all participants according to physical function status $(\mathrm{N}=1272)$ 


\begin{tabular}{|c|c|c|c|c|c|c|}
\hline \multirow[t]{2}{*}{ Characteristics } & \multicolumn{3}{|c|}{ Walking speed status } & \multicolumn{3}{|c|}{ Grip strength status } \\
\hline & Normal & Slow & $\mathbf{p}$ & Normal & Weak & $\mathbf{p}$ \\
\hline Women, n (\%) & $\begin{array}{l}265 \\
(56.5)\end{array}$ & $\begin{array}{l}429 \\
(53.4)\end{array}$ & 0.287 & $\begin{array}{l}340 \\
(45.6)\end{array}$ & $\begin{array}{l}354 \\
(67.3)\end{array}$ & $<0.001$ \\
\hline Age group, n (\%), 70 y. & $\begin{array}{l}267 \\
(56.9)\end{array}$ & $\begin{array}{l}312 \\
(38.9)\end{array}$ & & $\begin{array}{l}421 \\
(56.4)\end{array}$ & $\begin{array}{l}158 \\
(30.0)\end{array}$ & \\
\hline $80 \mathrm{y}$. & $\begin{array}{l}196 \\
(41.8)\end{array}$ & $\begin{array}{l}413 \\
(51.4)\end{array}$ & $<0.001$ & $\begin{array}{l}305 \\
(40.9)\end{array}$ & $\begin{array}{l}304 \\
(57.8)\end{array}$ & $<0.001$ \\
\hline $90 \mathrm{y}$. & $6(1.3)$ & $78(9.7)$ & & $20(2.7)$ & $64(12.2)$ & \\
\hline DM yes, (\%) & $67(14.3)$ & $\begin{array}{l}134 \\
(16.7)\end{array}$ & 0.257 & $\begin{array}{l}108 \\
(14.5)\end{array}$ & $93(17.7)$ & 0.123 \\
\hline HT yes, (\%) & $\begin{array}{l}304 \\
(64.8)\end{array}$ & $\begin{array}{l}615 \\
(76.6)\end{array}$ & $<0.001$ & $\begin{array}{l}533 \\
(71.4)\end{array}$ & $\begin{array}{l}386 \\
(73.4)\end{array}$ & 0.448 \\
\hline DLP yes, (\%) & $\begin{array}{l}290 \\
(61.8)\end{array}$ & $\begin{array}{l}470 \\
(58.5)\end{array}$ & 0.246 & $\begin{array}{l}458 \\
(61.4)\end{array}$ & $\begin{array}{l}302 \\
(57.4)\end{array}$ & 0.154 \\
\hline $\begin{array}{l}\text { Smoking status, Never, } \\
\text { (yes), n (\%) }\end{array}$ & $314(67)$ & $\begin{array}{l}497 \\
(61.9)\end{array}$ & 0.070 & $\begin{array}{l}431 \\
(57.8)\end{array}$ & $\begin{array}{l}380 \\
(72.2)\end{array}$ & $<0.001$ \\
\hline (\%) $\quad$ Ever, (yes), $\mathrm{n}$ & $\begin{array}{l}155 \\
(33.0)\end{array}$ & $\begin{array}{l}306 \\
(38.1)\end{array}$ & & $\begin{array}{l}315 \\
(42.2)\end{array}$ & $\begin{array}{l}146 \\
(27.8)\end{array}$ & \\
\hline $\begin{array}{l}\text { Slow walking speed*, yes, } \\
(\%)\end{array}$ & & & & $\begin{array}{l}429 \\
(57.5)\end{array}$ & $\begin{array}{l}374 \\
(71.1)\end{array}$ & $<0.001$ \\
\hline Weak grip strength*, yes, (\%) & $\begin{array}{l}152 \\
(32.4)\end{array}$ & $\begin{array}{l}374 \\
(46.6)\end{array}$ & $<0.001$ & & & \\
\hline SBP, mmHg, M (SD) & $\begin{array}{l}144 \\
(48.7)\end{array}$ & $\begin{array}{l}146 \\
(28.7)\end{array}$ & 0.668 & $\begin{array}{l}146 \\
(43.4)\end{array}$ & $\begin{array}{l}145 \\
(26.4)\end{array}$ & 0.715 \\
\hline DBP, mmHg, M (SD) & $83(49.0)$ & $79(25.5)$ & 0.133 & $82(42.9)$ & $78(22.7)$ & 0.031 \\
\hline LDL-C (mg/dL), M (SD) & $\begin{array}{l}122.4 \\
(29.4)\end{array}$ & $\begin{array}{l}119.8 \\
(29.1)\end{array}$ & 0.131 & $\begin{array}{l}121.9 \\
(29.4)\end{array}$ & $\begin{array}{l}119.2 \\
(28.9)\end{array}$ & 0.103 \\
\hline HDL-C (mg/dL), M (SD) & $\begin{array}{l}62.0 \\
(16.7)\end{array}$ & $\begin{array}{l}59.6 \\
(15.1)\end{array}$ & 0.011 & $\begin{array}{l}60.4 \\
(15.9)\end{array}$ & $\begin{array}{l}60.7 \\
(15.4)\end{array}$ & 0.687 \\
\hline $\mathrm{TCHO}(\mathrm{mg} / \mathrm{dL}), \mathrm{M}(\mathrm{SD})$ & $\begin{array}{l}211.9 \\
(34.7)\end{array}$ & $\begin{array}{l}205.8 \\
(34.1)\end{array}$ & 0.002 & $\begin{array}{l}209.8 \\
(34.0)\end{array}$ & $\begin{array}{l}205.5 \\
(34.9)\end{array}$ & 0.030 \\
\hline Albumin (g/dL), M (SD) & $\begin{array}{l}4.41 \\
(0.27)\end{array}$ & $\begin{array}{l}4.33 \\
(0.27)\end{array}$ & $<0.001$ & $\begin{array}{l}4.39 \\
(0.26)\end{array}$ & $\begin{array}{l}4.32 \\
(0.29)\end{array}$ & $<0.001$ \\
\hline $\mathrm{HbA1c}(\mathrm{mg} / \mathrm{dl}), \mathrm{M}(\mathrm{SD})$ & $5.5(0.6)$ & $5.6(0.7)$ & 0.253 & $5.5(0.6)$ & $5.6(0.6)$ & 0.102 \\
\hline BMI $\left(\mathrm{kg} / \mathrm{m}^{2}\right), \mathrm{M}(\mathrm{SD})$ & $22.3(2.8)$ & $22.7(3.1)$ & 0.069 & $\begin{array}{l}22.9 \\
(2.9)\end{array}$ & $22.1(3.0)$ & $<0.001$ \\
\hline
\end{tabular}




\begin{tabular}{|lllllll|}
\hline Characteristics & \multicolumn{3}{l}{ Walking speed status } & \multicolumn{4}{l|}{ Grip strength status } \\
& Normal & Slow & p & Normal & Weak & p \\
\hline Mean IMT (mm), M (SD) & 0.81 & 0.85 & $<0.001$ & 0.80 & 0.85 & $<0.001$ \\
& $(0.17)$ & $(0.16)$ & & $(0.16)$ & $(0.18)$ & \\
\hline
\end{tabular}

*See text on physical function of methods for details on how the status was defined.

DM indicates Diabetes mellitus; HT, Hypertension; DLP, Dyslipidemia; SBP, Systolic blood pressure; DBP, Diastolic blood pressure; LDL-C, Low-density lipoprotein cholesterol; HDL-C, High-density lipoprotein cholesterol; TCHO, Total cholesterol; HbA1c, Hemoglobin A1c; BMI, Body mass index; Mean IMT, Mean Intima-media thickness; $p$, p-value; M, Mean; SD, Standard deviation.

The association and hazard ratios between walking speed, grip strength, and CHD are presented in Table 3. In all participants, a slow walking speed at the baseline was significantly correlated with CHD after all confounder adjustment $(\mathrm{HR}=2.53,95 \% \mathrm{Cl}, 1.20-5.33, \mathrm{p}=0.015)$. Grip strength was not significantly correlated with $\mathrm{CHD}$ across all models. On sex stratification, a slow walking speed was associated with $\mathrm{CHD}$ after full adjustment $(\mathrm{HR}=4.78,95 \% \mathrm{Cl}, 1.07-21.35, \mathrm{p}=0.040)$ in women only. Weak grip strength at baseline was associated with $\mathrm{CHD}$ after age adjustment $(\mathrm{HR}=2.45,95 \% \mathrm{Cl}, 1.03-5.81, \mathrm{p}=0.043)$ in men only. However, after additional multivariate adjustment, the associations were weaker.

Table 3. Hazard Ratios for the association between walking speed, grip strength, and coronary heart disease 


\begin{tabular}{|c|c|c|c|c|c|c|c|c|}
\hline & $\begin{array}{l}\text { Model } 1 \\
\text { HR } \\
(95 \% \mathrm{Cl})\end{array}$ & $p$ & $\begin{array}{l}\text { Model } 2 \\
\text { HR } \\
(95 \% \mathrm{Cl})\end{array}$ & $p$ & $\begin{array}{l}\text { Model } 3 \\
\text { HR } \\
(95 \% \mathrm{Cl})\end{array}$ & $p$ & $\begin{array}{l}\text { Model } 4 \\
\text { HR } \\
(95 \% \mathrm{Cl})\end{array}$ & $p$ \\
\hline \multicolumn{9}{|c|}{ All participants } \\
\hline $\begin{array}{l}\text { Slow } \\
\text { walking }\end{array}$ & $\begin{array}{l}2.53(1.21- \\
5.31)\end{array}$ & 0.014 & $\begin{array}{l}2.51(1.19- \\
5.28)\end{array}$ & 0.015 & $\begin{array}{l}2.52 \\
(1.99- \\
5.30)\end{array}$ & 0.015 & $\begin{array}{l}2.53 \\
(1.20- \\
5.33)\end{array}$ & 0.015 \\
\hline $\begin{array}{l}\text { Weak grip } \\
\text { strength }\end{array}$ & $\begin{array}{l}1.27(0.67- \\
2.41)\end{array}$ & 0.455 & $\begin{array}{l}1.31(0.69- \\
2.48)\end{array}$ & 0.406 & $\begin{array}{l}1.29 \\
(0.68- \\
2.45)\end{array}$ & 0.434 & $\begin{array}{l}1.31 \\
(0.69- \\
2.48)\end{array}$ & 0.410 \\
\hline \multicolumn{9}{|l|}{ Men } \\
\hline $\begin{array}{l}\text { Slow } \\
\text { walking }\end{array}$ & $\begin{array}{l}1.67(0.69- \\
4.01)\end{array}$ & 0.253 & $\begin{array}{l}1.63(0.70- \\
3.95)\end{array}$ & 0.283 & $\begin{array}{l}1.71 \\
(0.71- \\
4.11)\end{array}$ & 0.233 & $\begin{array}{l}1.68 \\
(0.69- \\
4.08)\end{array}$ & 0.253 \\
\hline $\begin{array}{l}\text { Weak grip } \\
\text { strength }\end{array}$ & $\begin{array}{l}2.45(1.03- \\
5.81)\end{array}$ & 0.043 & $\begin{array}{l}2.34(0.97- \\
5.59)\end{array}$ & 0.056 & $\begin{array}{l}2.39 \\
(1.00- \\
5.69)\end{array}$ & 0.050 & $\begin{array}{l}2.23 \\
(0.93- \\
5.35)\end{array}$ & 0.074 \\
\hline \multicolumn{9}{|l|}{ Women } \\
\hline $\begin{array}{l}\text { Slow } \\
\text { walking }\end{array}$ & $\begin{array}{l}5.22(1.18- \\
23.21)\end{array}$ & 0.030 & $\begin{array}{l}5.07(1.14- \\
22.55)\end{array}$ & 0.033 & $\begin{array}{l}4.90 \\
(1.10- \\
21.91)\end{array}$ & 0.038 & $\begin{array}{l}4.78 \\
(1.07- \\
21.35)\end{array}$ & 0.040 \\
\hline $\begin{array}{l}\text { Weak grip } \\
\text { strength }\end{array}$ & $\begin{array}{l}0.73(0.30- \\
1.81)\end{array}$ & 0.499 & $\begin{array}{l}0.84(0.34- \\
2.09)\end{array}$ & 0.700 & $\begin{array}{l}0.76 \\
(0.30- \\
1.90)\end{array}$ & 0.557 & $\begin{array}{l}0.89 \\
(0.35- \\
2.24)\end{array}$ & 0.799 \\
\hline
\end{tabular}

Model 1 includes adjustment for age and sex; Model 2 includes adjustment for diabetes, hypertension, dyslipidemia, and Model 1; Model 3 includes adjustment for smoking status, body mass index, and Model 1; Model 4 includes adjustment for full covariate factors; $95 \% \mathrm{Cl}, 95 \%$ Confidence Interval; $p$, $\mathrm{p}$-value.

\section{Discussion}

The 7-year follow-up study of community-dwelling older populations showed that slow walking at the baseline was a strong predictor of $\mathrm{CHD}$ in all populations and older women after adjusting for traditional risk factors of CHD, though not in men. All participants with a walking speed slower than $1 \mathrm{~m} / \mathrm{s}$ at the baseline had a 2.5 times increased risk of CHD, while those women with a slow walking speed had a 4.8 times increased risk of $\mathrm{CHD}$ than those who walk faster. Weak grip strength was significantly correlated with $\mathrm{CHD}$ in older men after adjustment for age but, after additional multivariate adjustment, the associations were weaker, and no such association was found in women.

We now know that active physical activity is valuable in preventing and reducing the risk of cardiovascular disease mortality $[27,28]$. Walking speed might reflect time spent on habitual physical 
activity [29], especially physical activity with moderate intensity, and it is the most common leisure activity and alternative to high-intensity exercise in older populations [30]. Thus, it could affect cardiopulmonary fitness and be helpful to release chronic stress and anxiety [31]. This is a novel finding that slow walking is a predictor of CHD in community-dwelling old populations. This supports the results of previous studies, showing that walking speed is linked to cardiovascular disease in general populations [32]. Several studies indicated that people who engage in active physical activity are less likely to show IMT than an inactive group [33,34]. Our results showed that those with a normal physical function (walking speed and grip strength) had a significantly lower IMT than those with a poorer physical function. Active physical activity would increase the HDL level, which plays an important role to decrease inflammatory biomarkers associated heart disease $[35,36]$. Consistent with the current analysis, it has been shown that all participants and women with faster walking have a significantly higher HDL than those with slower walking. These are important to explain the benefit of walking speed linked to physical activity to protect against coronary heart disease.

The results showed that weak grip strength was associated with $\mathrm{CHD}$ in older men after adjusting for age, but the association was not found after further adjustment, which could be due to the small sample size in men. However, our results revealed that walking speed had a stronger association with $\mathrm{CHD}$ than grip strength.

Sex differences in the association between walking speed and CHD in the current study could be due to four reasons. Firstly, the selective survival issue due to cardiovascular mortality in men is higher than women [37], which is a cause of women with CHD live longer than men. Secondly, there is the selection bias issue in frailty. The meta-analysis indicated that older women more tolerate frailty and lower mortality rate than men $[38,39]$. This is consistent with the results found that the prevalence of slow walking speed in women was increased by advanced age. Thirdly, the onset of CHD was difference between sexes. There were many reports indicated that older men tend to present $\mathrm{CHD}$ at a younger age than women [40-42]. The current findings showed a higher prevalence of new-onset CHD in men in the 70-year-old group, while the rate of CHD in women was higher in the 80-year-old group and in the 90-yearold group. Finally, the status of atherosclerosis (IMT) was similar in a group with a slower walking speed and weaker grip strength in both sexes at the baseline. Whereas SBP was slightly higher and HDL was lower in women with slow walking speed. As a result, slow walking speed cannot counter the progression of atherosclerosis in women. These phenomena are likely to influence the outcome.

\section{Conclusions}

Based on the results, walking speed may be a strong surrogate predictor of CHD risk among communitydwelling old populations after multivariate adjustment for traditional risk factors of coronary heart disease. This suggests that the clinical intervention for improving walking speed may lower the CHD risk in community-dwelling old populations.

\section{Limitations}


Our study has some limitations, CHD involved a small number of events, leading to insufficient power for subgroup analyses by age group, which would help to more fully understand the mechanism. The data were collected based on self-reports leading to recall bias and the possibility of misclassification bias resulting from underreporting of $\mathrm{CHD}$.

\section{Abbreviations}

SONIC study: Septuagenarians, Octogenarians, Nonagenarians Investigation with Centenarians study; CHD:Coronary heart disease; CVD:cardiovascular disease; AWGS:Asian working group for sarcopenia consensus; DM:Diabetes mellitus; NGSP:National Glycohemiglobin Standardization Program; HT:Hypertension; DLP:Dyslipidemia; LDL:Low-density lipoprotein cholesterol; HDL:High-density lipoprotein cholesterol; TG:Triglycerides; JAS:Japan Atherosclerosis Society; BMI:Body mass index; IMT:intima-media thickness;

\section{Declarations}

\section{Acknowledgments}

We are grateful to all participants of SONIC who participated in these studies. We sincerely appreciate the secretarial work and support of all the staff involved in the SONIC study.

*The members of the SONIC Study Group are as follows: Toshiaki Sekiguchi, Kentaro Tanaka, Tomoko Noma, Kazuya Taira, Naoko Wada, and Atsuko Higuchi at the Division of Health Sciences, Osaka University Graduate School of Medicine; Serina Yokoyama, Satomi Maeda, Motonori Nagasawa, and Taku Fujimoto at the Department of Geriatric and General Medicine, Osaka University Graduate School of Medicine; Kennichi Matsuda, Taiji Ogawa, Yuichi Mihara, Masahiro Kitamura, and Yoshinobu Maeda at Osaka University Graduate School of Dentistry.

Author Contributions: Conceptualized and designed the study: Klinpudtan, Kabayama, Gondo, Rakugi, and Kamide. Performed data acquisition: all authors. Performed analysis and interpretation: Klinpudtan, Kiyoshige, and Akagi. Prepared the manuscript and figures: Klinpudtan, Kabayama, Godai, and Kamide. All authors approved the final version for submission.

\section{Funding}

This study was supported in part by grants-in-aid from the Ministry of Education, Culture, Sports, Science, and Technology of Japan (K.K.: 19K07888, M.K.: 19K11138)

\section{Availability of data and materials}

The datasets used and/or analyzed during the current study are available from the corresponding author on reasonable request. 


\section{Ethics approval and consent to participate}

The study was approved by the Institutional Review Board of Osaka University Graduate School of Medicine, Dentistry and Human Sciences and the Tokyo Metropolitan Geriatric Hospital and Institute of Gerontology (Refs.266, H22-E9, 22 018, and 38) and all participants provided written informed consent to participate on-site prior to starting the survey.

\section{Consent for publication}

Not applicable.

\section{Competing interests}

All authors declare that they have no competing interests.

\section{References}

1. Kannel, William B., Levine BS. Coronary Heart Disease Risk in People 65 Years of Age and Older. Prog Cardiovasc Nurs. 2003;18(3):135-40.

2. Benjamin EJ, Blaha MJ, Chiuve SE, Cushman M, Das SR, Deo R, et al. Heart Disease and Stroke Statistics'2017 Update: A Report from the American Heart Association. Circulation. 2017;135: e146e603.

3. Psaty BM, Furberg CD, Kuller LH, Bild DE, Rautaharju PM, Polak JF, et al. Traditional risk factors and subclinical disease measures as predictors of first myocardial infarction in older adults: The Cardiovascular Health Study. Arch Intern Med. 1999;159(12):1339-47.

4. Kannel WB. Coronary heart disease risk factors in the elderly. Am J Geriatr Cardiol. 2002;11(2):101107.

5. Madhavan MV, Gersh BJ, Alexander KP, Granger CB, Stone GW. Coronary Artery Disease in Patients $\geq 80$ Years of Age. J Am Coll Cardiol. 2018;71(18):2015-2040. doi:10.1016/j.jacc.2017.12.068.

6. Villareal DT, Miller B V., Banks M, Fontana L, Sinacore DR, Klein S. Effect of lifestyle intervention on metabolic coronary heart disease risk factors in obese older adults. Am J Clin Nutr. 2006; 84(6):13171323.

7. Coats AJS, Forman DE, Haykowsky M, Kitzman DW, McNeil A, Campbell TS, et al. Physical function and exercise training in older patients with heart failure. Nature Reviews Cardiology. 2017; 14(9):550559.

8. O'Neill D, Forman DE. The importance of physical function as a clinical outcome: Assessment and enhancement. Clinical Cardiology. 2020; 43(2):108-117.

9. Yen HY, Lin LJ. Quality of life in older adults: Benefits from the productive engagement in physical activity. J Exerc Sci Fit. 2018; 16(2):49-54. 
10. Studenski S, Perera S, Patel K, Rosano C, Faulkner K, Inzitari M, et al. Gait speed and survival in older adults. JAMA - J Am Med Assoc. 2011; 305(1): 50-58.

11. Dodson JA, Arnold S V., Gosch KL, Gill TM, Spertus JA, Krumholz HM, et al. Slow Gait Speed and Risk of Mortality or Hospital Readmission after Myocardial Infarction in the Translational Research Investigating Underlying Disparities in Recovery from Acute Myocardial Infarction: Patients' Health Status Registry. J Am Geriatr Soc. 2016;64(3):596-601.

12. Afilalo J, Eisenberg MJ, Morin JF, Bergman H, Monette J, Noiseux N, et al. Gait speed as an incremental predictor of mortality and major morbidity in elderly patients undergoing cardiac surgery. J Am Coll Cardiol. 2010; 56(20):1668-76.

13. Kamiya K, Hamazaki N, Matsue Y, Mezzani A, Corrà U, Matsuzawa R, et al. Gait speed has comparable prognostic capability to six-minute walk distance in older patients with cardiovascular disease. Eur J Prev Cardiol. 2018; 25(2):212-219.

14. Leong DP, Teo KK, Rangarajan S, Lopez-Jaramillo P, Avezum A, Orlandini A, et al. Prognostic value of grip strength: Findings from the Prospective Urban Rural Epidemiology (PURE) study. Lancet. 2015; 386(9990):266-273. doi:10.1016/S0140-6736(14)62000-6.

15. Sasaki H, Kasagi F, Yamada M, Fujita S. Grip Strength Predicts Cause-Specific Mortality in MiddleAged and Elderly Persons. Am J Med. 2007; 120(4):337-342.

16. Beyer SE, Sanghvi MM, Aung N, Hosking A, Cooper JA, Paiva JM, et al. Prospective association between handgrip strength and cardiac structure and function in UK adults. PLoS One. 2018;13(3):e0193124.

17. Zhu R, Li W, Xia L, Yang X, Zhang B, Liu F, et al. Hand grip strength is associated with cardiopulmonary function in Chinese adults: Results from a cross-sectional study. J Exerc Sci Fit. 2020; 18(2):57-61.

18. Gondo Y, Masui Y, Kamide K, Ikebe K, Arai Y IT. A Longitudinal Cohort Study of the Older People as Part of a Centenarian Study. In: Encyclopedia of Geropsychology. Pachana NA. Singapore: Springer Science+Business Media Singapore; 2016; 2227-36.

19. Shimada H, Makizako H, Doi T, Yoshida D, Tsutsumimoto K, Anan Y, et al. Combined Prevalence of Frailty and Mild Cognitive Impairment in a Population ofElderly Japanese People. J Am Med Dir Assoc. 2013; 147:518-24.

20. Chen LK, Liu LK, Woo J, Assantachai P, Auyeung TW, Bahyah KS, et al. Sarcopenia in Asia: Consensus report of the Asian working group for sarcopenia. Journal of the American Medical Directors Association. 2014;15(2):95-101. doi: 10.1016/j.jamda.2013.11.025.

21. Haneda M, Noda M, Origasa H, Noto H, Yabe D, Fujita Y, et al. Japanese Clinical Practice Guideline for Diabetes 2016. Diabetol Int. 2018; 9(3):657-697.

22. Umemura S, Arima H, Arima S, Asayama K, Dohi Y, Hirooka Y, et al. The Japanese Society of Hypertension Guidelines for the Management of Hypertension (JSH 2019). Hypertension Research. 2019; 42: 1235-1481. 
23. Kinoshita M, Yokote $\mathrm{K}$, Arai H, lida M, Ishigaki Y, Ishibashi S, et al. Japan Atherosclerosis Society (JAS) guidelines for prevention of atherosclerotic cardiovascular diseases 2017. J Atheroscler Thromb. 2018; 25(9); 846-984.

24. Nezu T, Hosomi N, Aoki S, Matsumoto M. Carotid Intima-media thickness for atherosclerosis. Journal of Atherosclerosis and Thrombosis. 2016: 23: 18-31.

25. Kokubo Y, Watanabe M, Higashiyama A, Nakao YM, Nakamura F, Miyamoto Y. Impact of intimamedia thickness progression in the common carotid arteries on the risk of incident cardiovascular disease in the suita study. J Am Heart Assoc. 2018;7(11):e007720.

26. Andrade H, Mateo I, Morillas P, Quiles J. What Measure of Carotid Wall Thickening Is the Best Atherosclerotic Loading Score in the Hypertensive Patient: Maximum or Mean Value?. 2011;64(5):417-20.

27. Alves AJ, Viana JL, Cavalcante SL, Oliveira NL, Duarte JA, Mota J, et al. Physical activity in primary and secondary prevention of cardiovascular disease: Overview updated. World J Cardiol. 2016; 8(10): 575-583.

28. Winzer EB, Woitek F, Linke A. Physical activity in the prevention and treatment of coronary artery disease. Journal of the American Heart Association. 2018.7(4): e007725.

29. Wong CH, Wong SF, Pang WS, Azizah MY, Dass MJ. Habitual Walking and Its Correlation to Better Physical Function: Implications for Prevention of Physical Disability in Older Persons. Journals Gerontol Ser A Biol Sci Med Sci. 2003; 2003;58(6):555-560.

30. Tanasescu M, Leitzmann MF, Rimm EB, Willett WC, Stampfer MJ, Hu FB. Exercise type and intensity in relation to coronary heart disease in men. J Am Med Assoc. 2002;288(16):1994-2000.

31. Kvæl LAH, Bergland A, Telenius EW. Associations between physical function and depression in nursing home residents with mild and moderate dementia: A cross-sectional study. BMJ Open. 2017; 7:e016875.

32. Yates T, Zaccardi F, Dhalwani NN, Davies MJ, Bakrania K, Celis-Morales CA, et al. Association of walking pace and handgrip strength with all-cause, cardiovascular, and cancer mortality: A UK Biobank observational study. Eur Heart J. 2017; 43(14).3232-3240.

33. Elbaz A, Ripert M, Tavernier B, Février B, Zureik M, Gariépy J, et al. Common carotid artery intimamedia thickness, carotid plaques, and walking speed. Stroke. 2005; 36:2198-2202.

34. Hamer M, Kivimaki M, Lahiri A, Yerramasu A, Deanfield JE, Marmot MG, et al. Walking speed and subclinical atherosclerosis in healthy older adults: The Whitehall II study. Heart. 2010; 96:380-384.

35. Cesari M, Marzetti E, Laudisio A, Antonica L, Pahor M, Bernabei R, et al. Interaction of HDL cholesterol concentrations on the relationship between physical function and inflammation in communitydwelling older persons. Age Ageing. 2010; 39(1).74-80.

36. Landi F, Russo A, Cesari M, Pahor M, Bernabei R, Onder G. HDL-cholesterol and physical performance: Results from the ageing and longevity study in the sirente geographic area (ilSIRENTE Study). Age Ageing. 2007; 36(5).514-520. 
37. Bots SH, Peters SAE, Woodward M. Sex differences in coronary heart disease and stroke mortality: A global assessment of the effect of ageing between 1980 and 2010. BMJ Global Health. 2017.

38. Gordon EH, Peel NM, Samanta M, Theou O, Howlett SE, Hubbard RE. Sex differences in frailty: A systematic review and meta-analysis. Experimental Gerontology. 2017; 2(2): e000298.

39. Zhang Q, Guo H, Gu H, Zhao X. Gender-associated factors for frailty and their impact on hospitalization and mortality among community- dwelling older adults: A cross-sectional populationbased study. PeerJ. 2018; 6:e4326.

40. Hochman JS, Tamis JE, Thompson TD, Weaver WD, White HD, Van de Werf F, et al. Sex, clinical presentation, and outcome in patients with acute coronary syndromes. Global Use of Strategies to Open Occluded Coronary Arteries in Acute Coronary Syndromes Ilb Investigators. N Engl J Med. 1999;341:226-232. DOI: 10.1056/NEJM199907223410402

41. Vaccarino V, Parsons L, Every NR, Barron H V, Krumholz HM. Sex-based differences in early mortality after myocardial infarction. National Registry of Myocardial Infarction 2 Participants. N Engl J Med. 1999;341(4):217-225.

42. Trevisan C, Sergi G, Veronese N, Maggi S, Manzato E. Gender differences in coronary heart disease in elderly populations. Ital J Gender-Specific Med. 2017; 9(1): 71-83.

\section{Supplementary Files}

This is a list of supplementary files associated with this preprint. Click to download.

- Additionalfile1TableS1.doc

- Additionalfile2FigureS1.doc 